DOI: https://doi.org/10.24867/02BE26Skrbic

\title{
МОДЕЛОВАЊЕ, АНАЛИЗА И ОПТИМИЗАЦИЈА КОНТРОЛЕ БЕЖИЧНОГ ПУНАЧА БАТЕРИЈЕ ЗА ЕЛЕКТРИЧНИ АУТОМОБИЛ
}

\section{MODELLING, ANALYSIS AND CONTROL OPTIMIZATION OF WIRELESS BATTERY CHARGER FOR ELECTRIC VEHICLE}

\author{
Драгана Шкрбић, Факултет техничких наука, Нови Сад, Србија \\ Хесус А. Оливер, Политехнички универзитет, Мадрид, Шпанија \\ Владимир Катић, Факултет техничких наука, Нови Сад, Србија
}

\begin{abstract}
Област - ЕЛЕКТРОТЕХНИКА
Кратак садржај -У овом раду обрађено је моделовање, анализа и оптимизација контроле бежичног пуюача батерије за електричне аутомобиле. Приказани су резултати симулащија и донесени закључци. Анализирана су два начина контроле излазне снаге, која могу да буду примјењена. На крају је приказан дио урађеног експеримента.
\end{abstract}

Кључне ријечи: електрични аутомобил, бежични пуњач батерије

Abstract -In this paper is processed modelling, analysis and control optimization of wireless battery charger for electric vehicle. The simulation results and conclusions are presented. Two ways of controlling the output power were analyzed, which can be applied. Finally, the part of the experiment that was done is shown.

Key words: electric vehicle, wireless battery charger

\section{1. УВОД}

Проблем загађења животне средине и емисије штетних гасова све је актуелнији. Једно од рјешења је и замјена мотора са унутрашњим сагоријевањем (СУС) електричним. Због тога је употреба електричних аутомобила сваке године све већа. Међутим, проблеми њихове употребе су ограничен домет, мала доступност пуњача и дуго вријеме допуњавања батерија. Пуњење батерија се може вршити кондуктивно (кабелски, жично) и бежично. У овом раду се разматрају само бежични системи.

Бежично пуњење батерија електричног аутомобила функционише на принципу магнетне индуктивности и резонанце [1]. Бежични пренос се практично врши помоћу DC/AC претварача (инвертора) на примарној страни и AC/DC претварача (исправљача) на секундарној страни. Примарна и секундарна страна су повезане преко индуктивних калемова [2].

\section{НАПОМЕНА:}

Овај рад проистекао је из мастер рада, који је рађен на Политехничком универзитету у Мадриду и одбрањен на ФТН у Новом Саду у склопу студентске размене Ерасмус+ пројекта, а чији супервизор је био др Хесус А. Оливер, ванр. проф., а ментор др Владимир А. Катић, ред. проф.
Анализа оптималне ефикасности подразумјева израчунавање фактора испуне исправљача. Вриједност се добија помоћу MPPT (eng. maximum power point tracking) алгоритма, који израчунава максималну снагу на бази улазних напона и струје. Током анализе оптималне ефикасности неопходно је размотрити три аспекта: фазни став између DC/AC и AC/DC претварача, вриједност напона DC кола и утицај coupling фактора.

Управљање може бити реализовано на два начина: 1 . контролом излазне снаге помоћу фазног помјераја између DC/AC и AC/DC претварача и 2. контролом излазне снаге помоћу DC напона АC претварача.

У раду је представљен модел овог пуњача, урађена је симулација пуњења батерије и дјелимично реализована експериментална потврда.

\section{2. ЕЛЕКТРИЧНИ АУТОМОБИЛИ}

Године 1834-те Томас Девенпорт конструисао је први електрични аутомобил, који је заправо био трицикл. Био је напајан из батерије, која нија имала могућност пуњења и користио се за кратке релације. Данас, после више од 125 година развоја СУС мотора, аутомобилска индустрија постепено прелази на електрични погон. Постоје три главна типа електричних аутомобила: хибридни електрични аутомобили (HEVs), plug-in хибридни електрични аутомобили (PHEVs) и потпуни електрични аутомобили (FEVs). Основна разлика између ових типова аутомобила је да посљедња два посједују батерије које могу бити екстерно пуњене [3].

Бежични начин пуњења батерија базира на развијеној регулативи. SAE J2954 је установљена препорука која дефинише критеријуме за електромагнетну компатибилност, минималне перформансе, сигурност и тестирање бежичног пуњења и plug-in електричних аутомобила. Стандард за бежични пренос енергије (WPT) заснован је на различитим нивоима, који треба да обезбиједе селекцију нивоа пуњења по тржишним критеријумима. Ово омогућава бољу опрему аутомобила и лакше кориштење.

\section{3. АНАЛИЗА ОПТИМАЛНЕ ЕФИКАСНОСТИ}

Приликом анализе оптималне ефикасности бежичног пуњења батерије електричног аутомобила неопходно 
је размотрити сљедеће аспекте: фазни став између DC/AC и AC/DC претварача; вриједност напона DC кола и утицај coupling фактора $(k)$.

Прије претходно наведених анализа, потребно је одредити оптималну вриједност факора испуне $d$ AC/DC претварача за максималну излазну снагу. Прва симулација је урађена са чисто отпорним потрошачем вредности 24,26 $\Omega$, у паралели са излазним кондензатором (слика 1) [4].

\section{1. Анализа фазног става између претварача}

За анализу фазног става између DC/AC и AC/DC претварача искоришћена је симулациона шема приказана на слици 2. Потрошач је константан напонски извор вриједности $300 \mathrm{~V}$, а пренос снаге зависи од фазног помјераја. Резонантна фреквенција за кориштене параметре кола је $85 \mathrm{kHz}$.

\section{2. Анализа вриједности напона DC кола}

За анализу напона DC кола потребно је симулацију са слике 2 модификовати тако да напонски извор на излазу буде контролисан, а фазни помјерај између $\mathrm{DC} / \mathrm{AC}$ и AC/DC претварача фиксан. Изабран је фазни помјерај од $90^{\circ}$, јер се тада обезбеђује најбоља ефикасност. Напонски извор је управљан MPPT алгоритмом, а за почетну вриједност узета је вриједност од $300 \mathrm{~V}$. Вриједности параметара у овој симулацији су: фазни став DC/AC претварача је $90^{\circ}$, фазни став $\mathrm{AC} / \mathrm{DC}$ претварача је $0^{\circ}, k=0,25$ и $d=0,5$. Добијена је вриједност излазне снаге од $7100 \mathrm{~W}$, а резултати су приказани на слици 3.

\section{3. Анализа утицаја coupling фактора}

Coupling фактор $(k)$ је од изузетне важности за бежични пренос енергије. Њиме се изражава међусобна спрегнутост калемова који преносе енергију. Изражава се сљедећом формулом:

$$
k=\frac{M}{\sqrt{L_{1}-L_{2}}}
$$

Утицај coupling фактора је размотрен на симулацији са константним напонским извором (слика 2). Прво су претпостављени сљедећи параметри: фазни став $\mathrm{DC} / \mathrm{AC}$ претварача је $90^{\circ}$, фазни став AC/DC претварача је $0^{\circ}, k=0,187$ и $d=0,5$. Добијена је излазна снага $5260 \mathrm{~W}$, а на слици 4 су приказани напон и струја на секундарној страни.

У другом кораку коришћени су исти параметри, само je повећан coupling фактор на $k=0,25$. Добијена је излазна снага $7100 \mathrm{~W}$, односно исте вредности као на слици 3.

Такође, размотрен је и утицај ниже вредности $k$. За $k=0,109$ добијена је излазна снага од $3000 \mathrm{~W}$, а напон и струја нису фазно усклађени. Закључено је да мање вриједности coupling фактора не одговарају.

\section{4. КОНТРОЛА}

Разматрана су два система управљања (контроле) излазне снаге: 1. помоћу фазног помјераја између $\mathrm{DC} / \mathrm{AC}$ и AC/DC претварача, и 2. помоћу DC напона АC претварача.

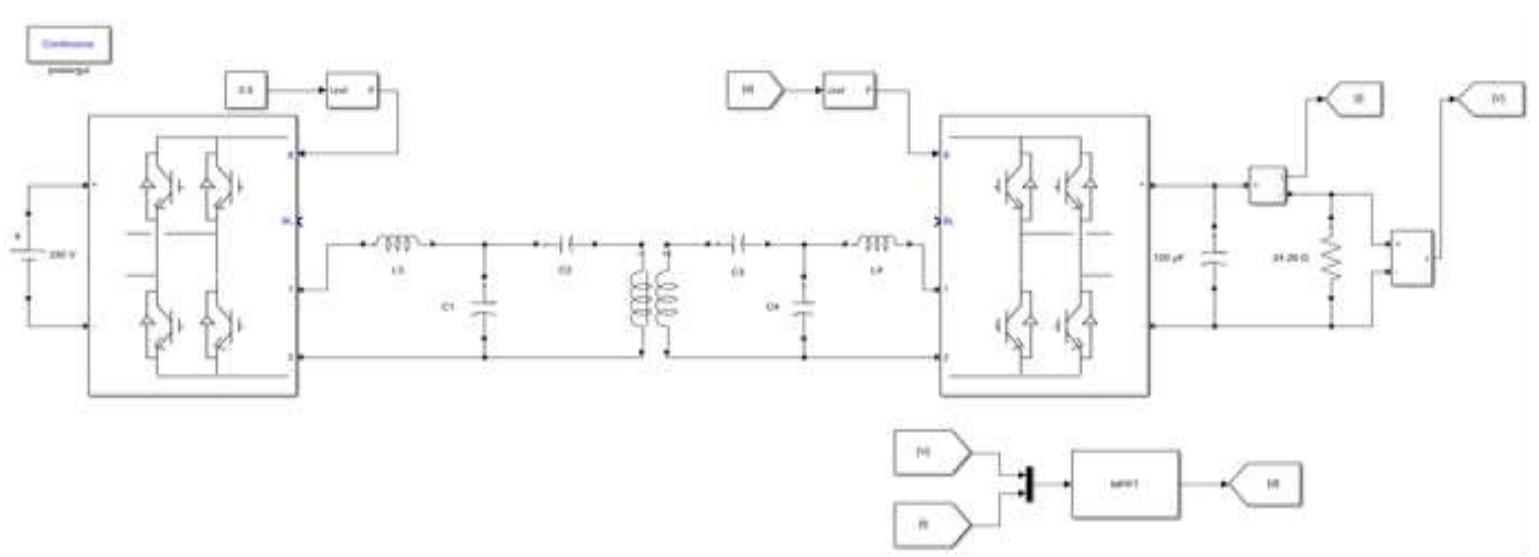

Слика 1. Симулациона шема са отпорним потрошачем.

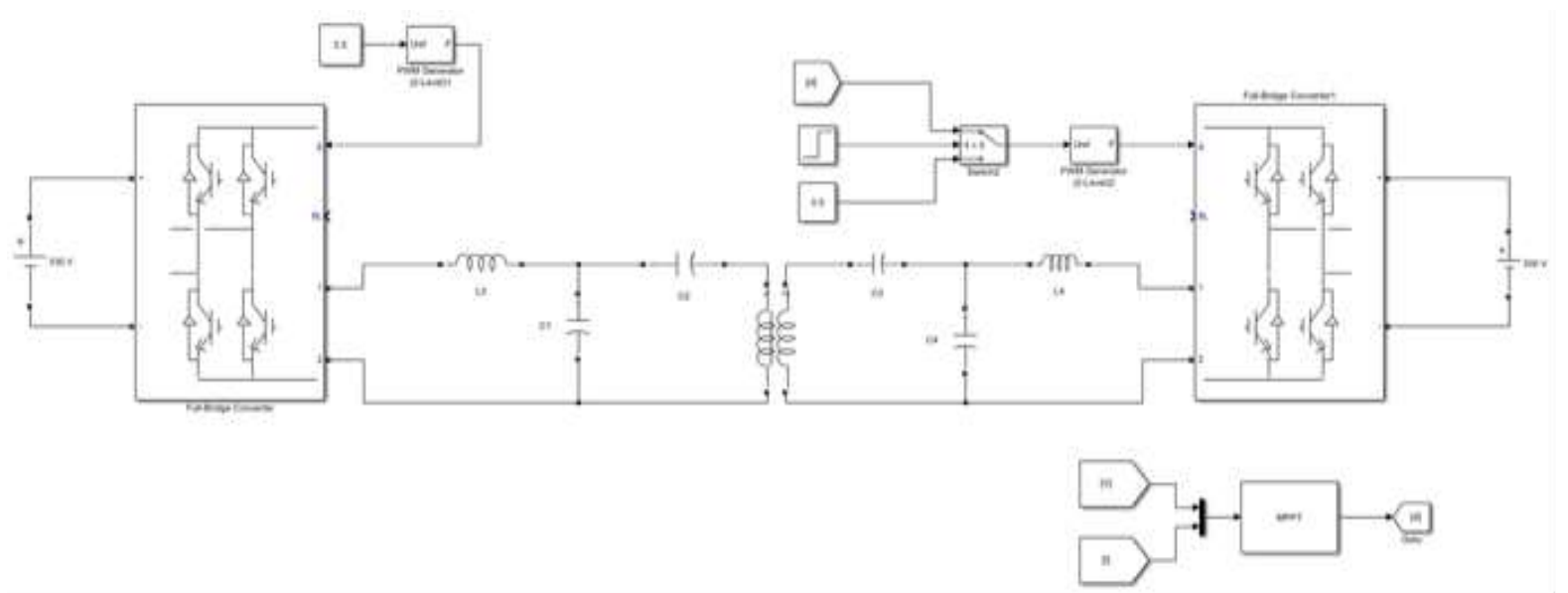

Слика 2. Симулаџиона шема са константним напонским извором као потрошачем. 

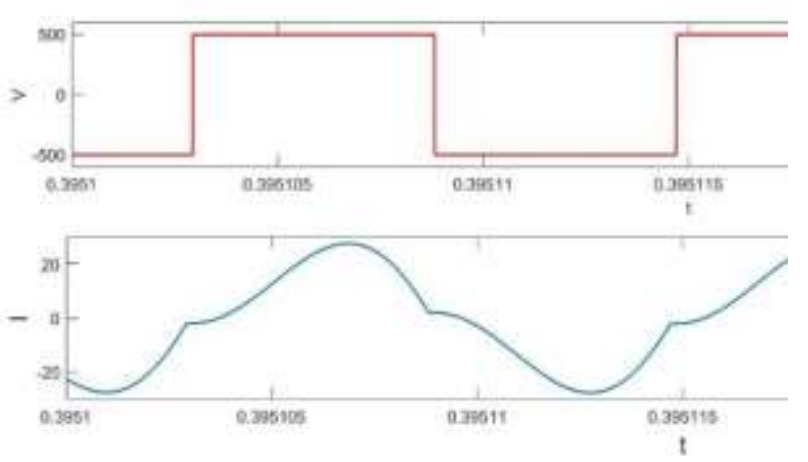

Слика 3. Резултати симулащије за $k=0,25$ u $d=0,5$.
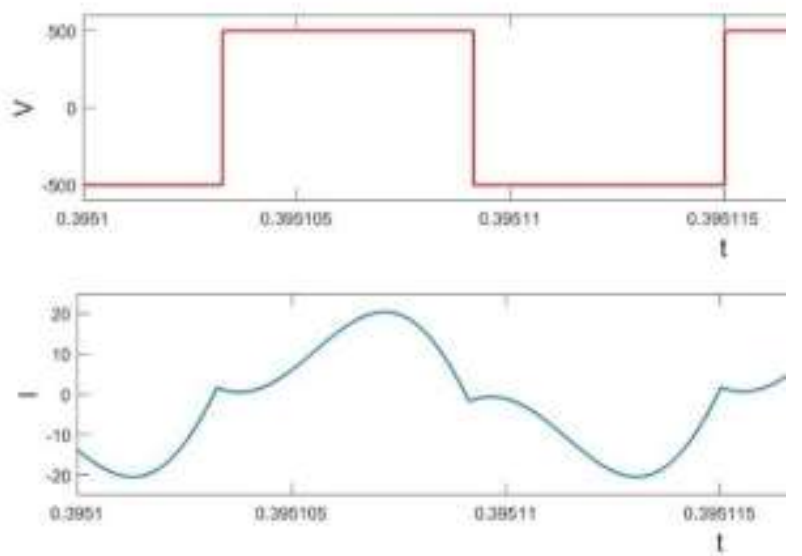

\section{1. Контрола излазне снаге помоћу фазног} помјераја између DC/AC и AC/DC претварача

Прво је урађена симулација са константним напонским извором од $300 \mathrm{~V}$ (слика 5). Ту је контролисана излазна снага помоћу фазног помјераја између претварача. Утврђено је да је потребно испоручити мању снагу, ако је фазни помјерај између $\mathrm{DC} / \mathrm{AC}$ и $\mathrm{AC} / \mathrm{DC}$ већи.

\section{2. Контрола излазне снаге помоћу DC напона $\mathrm{AC}$ претварача}

Током анализа закључено је да је излазни DC напон линерно повезан са излазном снагом ако је струја константна, што значи да ако повећавамо вриједност излазног напона и излазна снага ће се повећати. Да би то било приказано на мало занимљивији начин одрађена је симулација пуњења батерије.

Симулациона шема пуњења батерије приказана је на слици 6. Умјесто константног напонског извора на излазу користи се велики кондензатор, чија капацитивност је $0,2667 \mathrm{~F}$ и који заправо представља батерију. Струја на излазу је константна и износи 10 А. Референца за контролу снаге се добија тако што се множе константна струја и измјерени напон на кондензатору. Фазни помјерај је фиксан и износи $45^{\circ}$. Резултати симулације, тј. приказ односа излазне струје и напона, односно снаге пуњења батерије дати су на слици 7.

Слика 4. Резултати симулащије за $k=0,189$ u $d=0,5$.

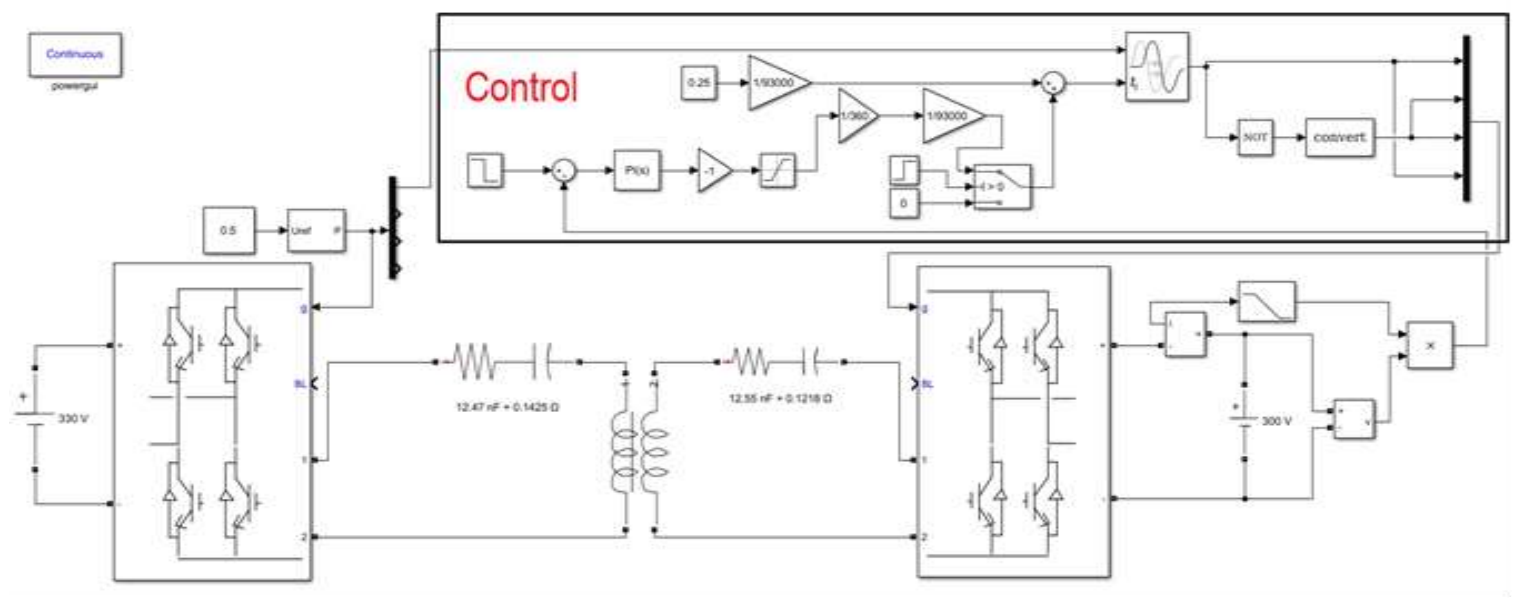

Слика 5. Симулациона шема са константним напонским извором за први начин контроле

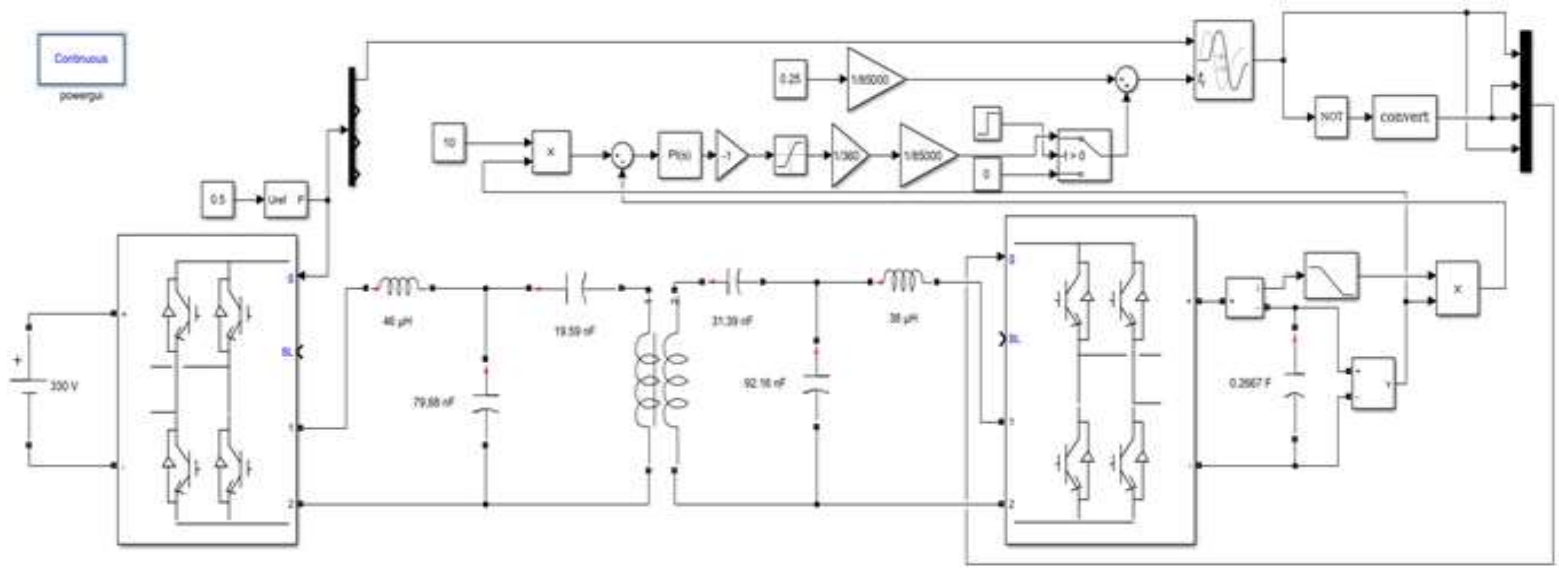

Слика 6. Симулациона шема пуњења батерије. 


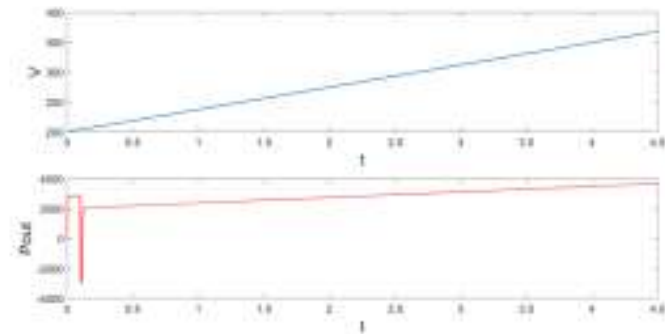

Слика 7. Резултати симулащије пуњења батерије.

\section{5. ЕКСПЕРИМЕНТАЛНА ПРОВЈЕРА}

Резултати симулација контроле излазне снаге дјелимично су провјерени на лабораторијском прототипу који има LC топологију (слика 8). Прототип има следеће параметре примарне и секундардне стране бежичног пуњача: $\mathrm{L}_{1}=228,7 \mu \mathrm{H}+$ $0,415 \Omega ; \mathrm{L}_{2}=207,3 \mu \mathrm{H}+0,318 \Omega$ и $k=0,2$. Резонантни кондензатори су: $\mathrm{C}_{1}=12,47 \mathrm{nF}+0,1425 \Omega$ и $\mathrm{C}_{2}=12,55$ $\mathrm{nF}+0,1218 \Omega$. За струјно и напонско мјерење коришћени су већ постојећи сензори, који су прилагођени вриједностима прототипа. На сликама 9 и 10 приказани су резултати напонског и струјног тестирање, респективно. Може се уочити линеарни одзив, односно адекватно прилагођење реалних вредности параметрима аналогних улаза $D S P$-а.

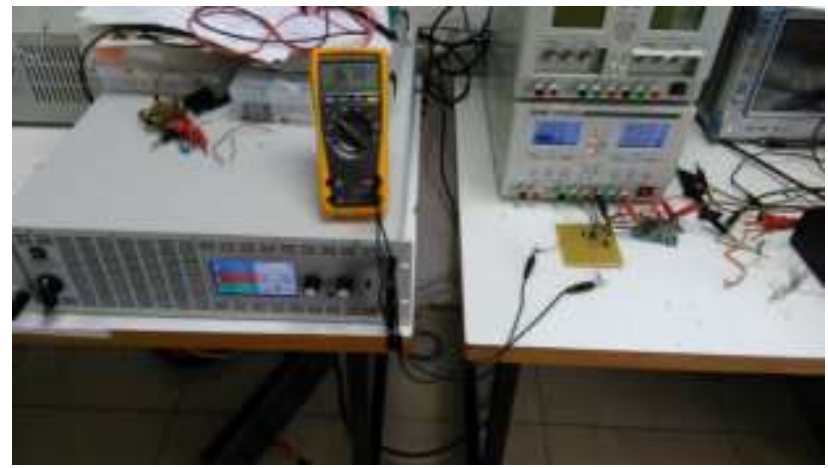

Слика 8. Приказ експерименталне поставке.

\section{6. ЗАКЉУЧАК}

У раду је изложена проблематика бежичног начина пуњења електричних аутомобила. Установљени су најбољи начини подешавања претварача у циљу максималне ефикасности. Такође је показано како вриједност напона у DC колу утиче на излазну снагу. Обрађена су два начина контроле пуњења. Корисник бира у складу са својим захтјевима најбољи начин. На крају је у експерименталном дијелу потврђен линеаран одзив за струјно и напонско мјерење.

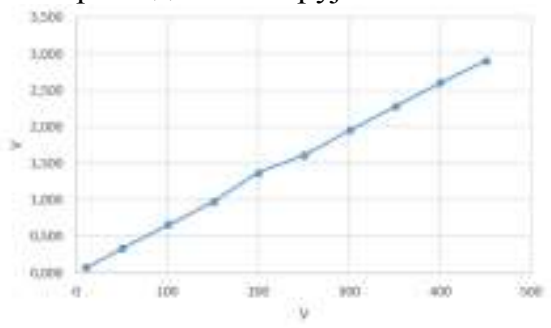

Слика 9. Резултати напонског тестирања.

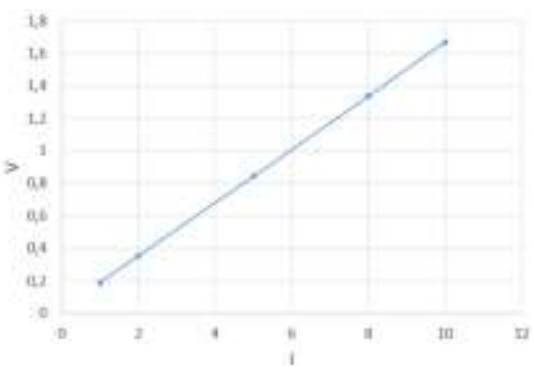

Слика 10. Резултати струјног тестирања

\section{7. ЛИТЕРАТУРА}

[1] D. Maksimović, R.W. Erickson, "Fundamentals of Power Electronics”, $2^{\text {nd }}$ Ed., Kluwer Academic Publishers, New York, 2004.

[2] T.M. Fisher, K.B. Farley, Z. Gao, H. Bai, Z. Ho Tse, "Electric vehicle wireless charging technology: a state-of-the-art review of magnetic coupling systems", Wireless Power Transfer, Vol.1, Issue 2, Sep.2014, pp.87-96.

[3] A. Berger, M. Agostinelli, S. Vesti, J. A. Oliver, J.A. Cobos, M. Huemer, "A Wireless Charging System Applying Phase-Shiftand Amplitude Control to Maximize Efficiencyand Extractable Power", IEEE Trans. on Power Electronics, Vol.30, No.11, Nov. 2015, pp.6338 - 6348.

[4] A. Poullikkas, "Sustainable options for electric vehicle technologies", Renewable and Sustainable Energy Reviews, vol. 41(C), 2015, pp.1277-1287.

\section{Кратка биографија:}

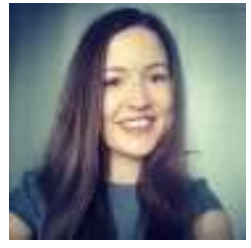

Драгана Шкрбић, дипл. инж. рођена је 1994. године у Мркоњић Граду. Факултет техничких наука, студијски програм Енергетика, електроника и телекомуникације (ОАC) уписала је школске 2013/2014. На студијама се опредијелила за модул Електро-енергетика - Енергетска електроника и електричне машине и дипломирала 2017. год. Мастер студије истог модула завршила је 2018. год.

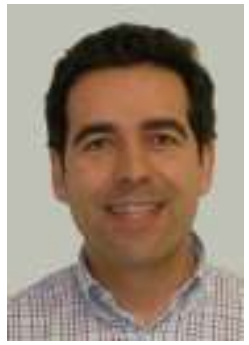

Хесус А. Оливер (Jesus A. Oliver), ванр. проф. рођен је у Толеду, Шпанија 1972. год. Мастер и докторске студије завршио је на Политехничком универзитету у Мадриду, Шпанија 1996. и 2007. год., респективно. Области интересовања су моделовање и управљање уређаја енергетске електронике, системи са горивим ћелијама и енергетска ефикасност.

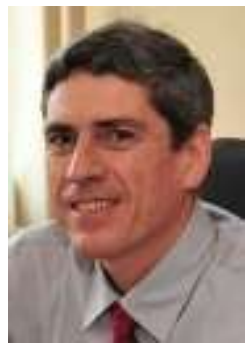

Владимир А. Катић, ред.проф. рођен је 1954. године у Новом Саду. Дипломирао j на Факултету техничких наука у Новом Саду 1978. год., а магистрирао и докторирао на Електротехничком факултету Универзитета у Београду 1981. и 1991. год., респективно. Области интересовања су енергетска електроника, обновљиви извори и квалитет електричне енергије, и електрична возила. 